\title{
A History of Urban Planning and Infectious Diseases: Colonial Senegal in the Early Twentieth Century
}

\author{
Liora Bigon \\ Department of History and Theory, Bezalel Academy of Arts and Design, Mount Scopus, Jerusalem 91240, Israel \\ Correspondence should be addressed to Liora Bigon, liorin@hotmail.com
}

Received 28 June 2011; Revised 13 December 2011; Accepted 31 December 2011

Academic Editor: Faranak Miraftab

Copyright ( 2012 Liora Bigon. This is an open access article distributed under the Creative Commons Attribution License, which permits unrestricted use, distribution, and reproduction in any medium, provided the original work is properly cited.

This paper deals with the spatial implications of the French sanitary policies in early colonial urban Senegal. It focuses on the French politics of residential segregation following the outbreak of the bubonic plague in Dakar in 1914, and their precedents in Saint Louis. These policies can be conceived as most dramatic, resulting in a displacement of a considerable portion of the indigenous population, who did not want or could not afford to build à l'européen, to the margins of the colonial city. Aspects of residential segregation are analysed here through the perspective of cultural history and history of colonial planning and architecture, in contrast to the existing literature on this topic. The latter dilates on the statutory policies of the colonial authorities facing the 1914 plague in Dakar, the plague's sociopolitical implications, and the colonial politics of public health there. In the light of relevant historiography, and a variety of secondary and primary sources, this paper exposes the contradictions that were inherent in the French colonial regime in West Africa. These contradictions were wisely used by the African agency, so that such a seemingly urgent segregationist project was actually never accomplished.

\section{A Note on Historiography}

The aim of this paper is to explore the spatial aspects of French sanitary policies in early colonial, urban Senegal, focusing on Dakar and Saint Louis. The spatial analysis of the French politics of residential segregation following the outbreak of bubonic plague in Dakar in 1914 (and previous cases both there and in Saint Louis) can be illuminating, based upon the existing literature on the topic. Consisting of just a few works, this literature deals less with the cultural history of urban planning and architecture, and more with the statutory policies of the colonial authorities facing the 1914 plague (Seck, Salleras), the plague's sociopolitical implications (Betts, M'Bokolo), and the colonial politics of public health there (Echenberg) [1-5].

A wider historiographic view reveals that critical works on the history of colonial sanitary and public health policies in sub-Saharan Africa is a bourgeoning field, though the urban space per se is not normally their main focus. (See, for instance (partial list, in chronological order): [6-10].) The history of colonial urban space in sub-Saharan Africa has also become a growing field. It can be argued in general that the anglophone research tradition into the colonial urban sphere in Africa has dealt with history-in-the-city, the history of social movements and popular struggles around community issues - such as, and these are only arbitrary examples, Cooper on French West Africa and British East Africa, White on Kenya, Van Onselen on South Africa, and Parker on Ghana [11-15]. The francophone research tradition, on the other hand, has dealt with the historyof-the-city itself. (This latter distinction is based on [16] (page 20). Seck's aforementioned work on Dakar can be considered as an exemplary case of this research tendency (see [1-5]).) It should be noted that exceptions to the general research trends described above do of course exist, as will be mentioned below.

As remarked by Catherine Coquery-Vidrovitch in her comprehensive overview of the history of urbanisation and urban planning in Africa, however, "it appears desirable to build a bridge between the two approaches and to combine their methods in order to grasp both the content and the container ([17] page 19)." While this characterisation is surprisingly actual $([18,19]$ while the first source surprisingly ignores the French literature, the "urban spaces" in 
the second are mainly used as a background for social interactions), it seems that this bridge has indeed been built, especially during the last two decades. This paper conforms to the spirit of a series of pioneering works that critically examine the history of colonial urban spaces, taking into account both the spatial and architectural urban form and its sociopolitical and cultural implications. Amongst the authors of recent book-length studies that concerns subSaharan Africa in these regard, can be mentioned Fourchard, Goerg, Home, Lagae, Myers, Sinou, Soulillou, and Toulier. (Some of these works (partial list), given in chronological order, are comparative, and sub-Saharan Africa is included in them beside other colonial territories [20-31]).

Segregationist policies as a key feature in colonial urbanism have also attracted much critical research attention, especially in the postcolonial period. There is no doubt that one of the first book-length studies dealing thoroughly with the political, economic, cultural, and visual implications of these phenomena is that of Anthony King on British India ([32] while this study brilliantly reflected the side of the colonial society, only a few pages were dedicated in it to the colonised counterpart, a drawback that was later discussed and reasoned by the author). A survey article concerning sub-Saharan Africa that is equivalent in its pioneering approach to King's work is that of Philip Curtin [33]. However, while both of these studies can be considered the first swallows of spring, this academic "spring" tends to focus on the former colonies that enjoyed a relatively higher order of colonial preferences. Apart from British India, these included Australian cities, British Singapore, and French Indo-China-to give but a few examples [32, 34-37]. Similarly, colonial urban space, public health, and residential segregation in French North Africa and South Africa have received much more scholarly attention than their counterparts in sub-Saharan, tropical Africa. (For far from being inclusive a list, see (in chronological order) [38-46].)

Like the entire colonial urban space in Africa, as designed by France, Britain, Belgium, and other colonial powers, in imperial Dakar segregationist policies-or residential sectorialisation between the involved groups-played a key role. Whether formally or informally enforced, segregationist moves were tightly related to contemporary racial prejudices and assumptions concerning sanitation in tropical countries, especially in Africa. Against this background, Maynard Swanson's paper from the 1970s, dealing with the Cape Colony of South Africa in this regard, was one of the pioneers. Coining the notion "sanitation Syndrome" in the academic literature, Swanson argued that already by the early twentieth century, well before the initiation of the formal "apartheid" policy by an Afrikaner party in 1948, the African population of Cape Town was pushed out beyond its urban boundaries [47].

These spatial moves were related to the outbreak of bubonic plague in 1900, originating in southern China and spreading over the maritime routes. Though the contamination rate among the Africans was not higher than among the coloured or white populations, the plague was identified with the black population and the black population with the plague, embodying both biological fact and social metaphor. Considering the socio-economic tensions between the main urban sectors and the conception of the black population as a barbaric collective that threatened the order and health conditions in the "European" city, there is little wonder why the plague was used so dramatically by those who favoured segregationist measures as a social solution. Cape Town serves as a paradigm for contemporary Dakar, and for other colonial cities in Africa under French or other European regimes.

In spite of the fact that for various reasons the expatriate minority in the colonial period preferred to reside in a separate quarter wherever possible, segregationist moves varied in character amongst the colonial powers as to stated motives, statutory means, and the general political framework. It has been noted, for instance, that in West Africa the British authorities preferred a more institutionalised legislative framework for residential segregation between the coloniser and the colonised communities, especially under Lord Lugard [48]. Their French counterparts preferred the opposite, as will be shown below, drawing on a variety of other explanations. In addition, South Africa-as well as other colonies that were intended for white settlement such as Algeria or Southern Rhodesia-should be distinguished at this point from West Africa. Never designated for a permanent white settlement, both British and French colonial projects in West Africa were underfunded and understaffed. Consequently, the relatively minor friction between the white and the black communities there-a region that did not experience white nationalism, industrialisation or have a "poor white" class_-did not necessitate an enforcement of systematic or rigid residential segregation, backed by sanitary laws. (Some notes, beyond the scope of this paper, as recent study shows, even in the extreme case of South Africa under the apartheid regime, a "perfect system of control" was not achieved through the planning practices [49]. And there were, of course, more "grey" groups and spatialities between the "black" and the "white" societies in colonial Africa. In addition, there are some cases where residential segregation in the French colonies might be considered as more social than racial, that is, in the case of the "assimilated", who were permitted to live in the European quarter. See, inter alia, [50].)

Yet nevertheless, the establishment of the "Médina" by the French colonial authorities - that is, the new quarter in Dakar designated for the African population-was one of the most rigorous acts in the history of this city. This sudden move was not carefully planned, but rigidly enforced following an outbreak of bubonic plague in 1914. What started as a medical or pseudomedical issue gradually became a considerable urban and social problem, though this segregationist move was never fully completed. As a consequence, spontaneous and organised responses on the "African side" were felt, as well on the conceptual level, in terms of spatial perceptions and their influence on the usage of the urban area. For this reason, the colonial urban sphere should not be perceived as terrain for exercising uni-directional power by those with the formal political control over those colonised, but rather as a constantly challenged and contested sphere (This conception was developed, for instance, in [51-53].) In order to penetrate beyond the typical representation of 
the interests of the colonial authorities in archival documentation and to represent some of the spatial conceptions of contemporary inhabitants of Dakar, reading between the lines and even against the text was also necessary, backed by some field work. Colonial urban planning included a large array of related policy tools upon which sanitation laws relied on-such as zoning, taxation and state revenues, urban land claims, and political security. In this work, the reciprocal relationships between the sanitary debate in early twentieth century Senegal and the attempts to establish residential segregation on a racial basis in French Dakar will be discussed. These visual and conceptual aspects of the colonial urban space are also illuminated against the background of their nineteenth-century precedents in Dakar and Saint Louis.

\section{Infectious Diseases, Straw Huts, and Segregationist Plans in Pre-1914 Senegal}

If the consequences of the establishment of Dakar's Médina-an endeavour realised in July 1914 following a plague outbreak - were somewhat surprising, the initiative and atmosphere beyond it were not unprecedented in Dakar. Segregationist moves in pre-1914 Dakar were justified by health factors as well. "Dakar is, in fact, one of the places which interests the sanitarian as well as the traveller, the soldier and the trader as well as the doctor [54]," wrote A. Santelly, a naval doctor who served there between 1868 and 1870. The French presence in West Africa consisted from the second half of the seventeenth century of two urban settlements, established on islands, Saint Louis on the delta of the Senegal River and Gorée, opposite the mainland's Cap Vert peninsula, over which the future city of Dakar would be created (Figure 1). The Senegalese region, and later the Colony of Senegal, was conceived by the contemporary French expatriates as "terre des fièvres et de la barbarie" (land of infectious diseases and barbarity) ([55] (page 51)), in accordance with the general European conception of West Africa as "the white man's grave." In fact, on the Cap Vert peninsula every decade seemed to produce its own epidemics. Statistics show though that in almost every outbreak of yellow fever epidemic in Senegal throughout the nineteenth century, the death rate among European civilians was fifty percent or more. (The main killers thus were not intestine infections or physical accidents, but malaria and yellow fever. Upon the outbreak of a yellow fever epidemic in Saint Louis and Gorée in 1830, for instance, death rates were 573 per thousand, and 146 per thousand at the end of the plague [10]. See also [56].) This very high rate was one of the reasons why, for instance, there was a two-year delay in the construction of Dakar's military port in 1900, where many of the European workers became ill and died (hereafter [57]. In his letter to the Ministre des Colonies, the head of Hersent \& Fils company for public works complained that 49 per cent of his 93 European workers had become ill during the works on Dakar's portthe rate was still growing - and offered immediate measures that, in his opinion, would help ameliorate the situation).

In the same year, it was acknowledged that the miserable sanitary conditions of Dakar would "never allow the creation of a major settlement for Europeans" [58] there. On the other hand, since "Dakar's reputation for insalubrity [was] the most established among all French colonial cities ([59], page 7. Dr. Ribot had served as the Chief Doctor of the colonial troops in Senegal, and was now in charge of the sanitary services in Dakar)," the French authorities regarded the sanitation of this town - the façade of their colonial empire on the Atlantic - as a challenge. It was not only a matter of prestige, since every epidemic created in its turn a chaotic situation that endangered the entire colonial project there. As described by a Marseille-based company immediately after an outbreak of yellow fever in 1900, "the public services are disorganised, the [French] troops have been recalled, train traffic has been suspended, commercial stores have been closed... there is a general exodus of the white population, normal life in this country has been interrupted [60]."

Rather than regulating the whole of Dakar's urban space, contemporary sanitary legislation and projects actually segregated the two main communities. One of the first steps of the Comité d'hygiène et de salubrité publique, created in Senegal in the 1880s under the influence of metropolitan legislation, was the inspection of buildings [61]. The aim of the Comités Sanitary Brigades was to eliminate as many of the African straw huts. "Straw huts" in our context mean thatch-roofed buildings with walls made of straw (similar, for instance, to those shown in Figure 7). While in the Upper Senegal, Mali, and other parts along the Sudanic belt, there was a preference for using mud (banco) for permanent housing, mud building was impossible in the sandy dunes of the region of Cayor (Kajoor) - the coastal belt of Senegal (between Dakar and Saint Louis).) as possible in Dakar-ville, that is, the centre of the city and its older section. Planned in the second half of the nineteenth century, it was designated for the European expatriate community, meant to be built using permanent materials such as stone, and conceptualised as the very embodiment of "civilisation." In fact, measures for the elimination of the indigenous dwellings in Senegal's urban centres were already about one hundred years old.

As early as 1803, Saint-Louis's governor Blanchot promoted the use of brick for building rather than straw and taxed straw huts. A house made of bricks or stone consequently signified wealth, strength, and attachment to the influential European sector. The straw hut, by contrast, signified slavery and "barbarism" [62]. Prosperous families of merchants among the métis that adopted or imitated Western cultural values refused to live in "chaumières" (thatch-roofed huts) like the "nègres"Later, straw huts were also condemned in Saint-Louis's municipal laws, aimed to drive ex-slaves and small traders, who could not afford the use of brick, out of the crowded island, and to provide better protection against frequent outbreaks of fire ([63] See also an article by the [64]. The latter calls the colony's government to subsidise prefabricated houses for the poor fisherman, stating that with materials like straw the pompiers always come too late). Yet it is not clear how enforceable such laws were prior to formal colonisation, when the merchants' insistence on laissez faire was strong enough to be enforced on the governor. Indeed, the governor himself quite often collaborated with the interests of the local 


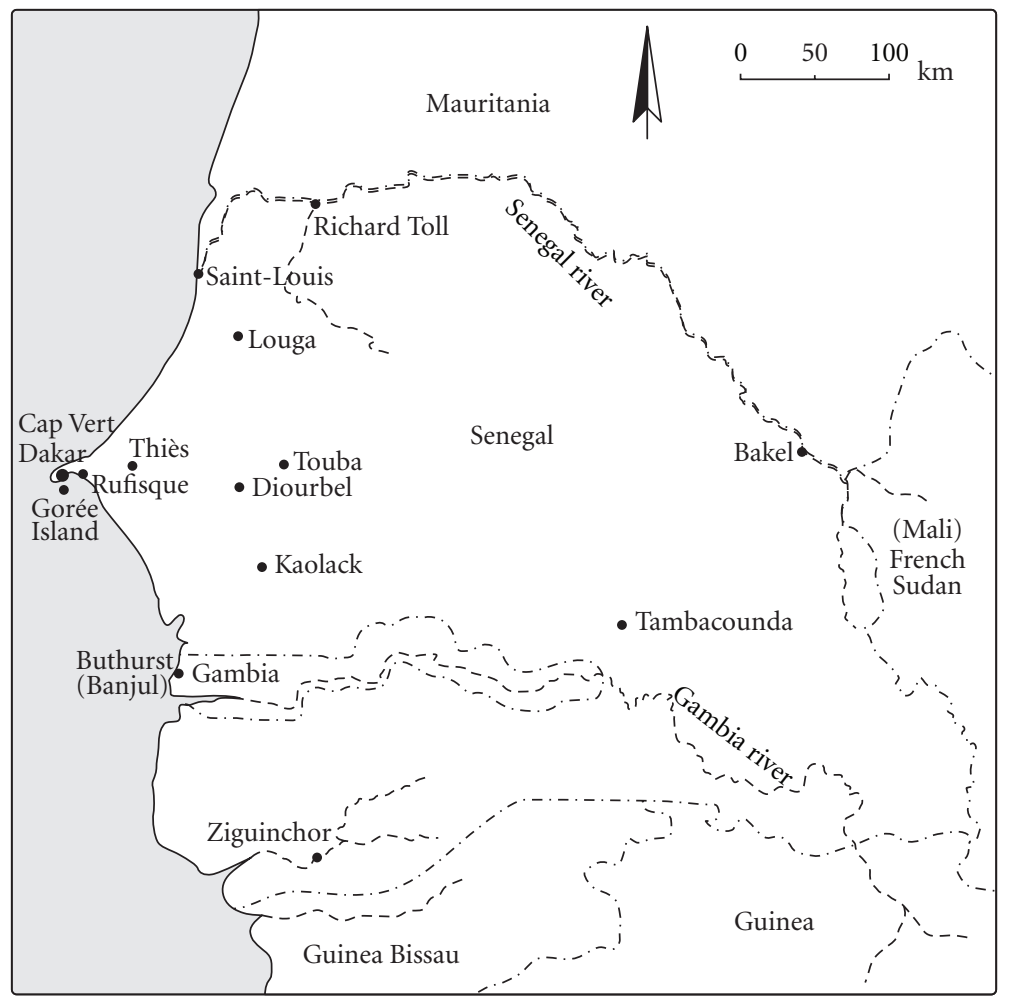

... International borders

Figure 1: Map showing the old French urban settlements which were named “les Quatre Communes du Sénégal.” Saint Louis (1659) served as a base for the French seizure of West Africa from along the Senegal River; the Island of Gorée (1678), where French merchants (and slavers) were concentrated, together with the métis community and the French Navy; Rufisque (1850), which orchestrated on the thriving groundnut trade with the hinterland; Dakar (1857), a strategic and the westernmost point in Africa. (Map made by the author).

dominant métis families, who used to select the town's mayor from among them. Even after the mid-nineteenth century, when measures were taken by the colonial authorities to get rid of the huts, using troops to do so [65], the straw-hutlandscape never entirely disappeared from Saint-Louis and Dakar. In fact, it became the ultimate image of Senegalese colonial towns.

Nineteenth century colonial novelists, such as Pierre Loti, contributed to the consolidation of the image of "black Africa" as an isolated, peculiar land, full of disease and death, and dotted with straw huts-the latter always bear negative connotations. In his famous Le Roman d'un Spahi, first published in 1883, whose hero is a French soldier positioned in Saint Louis, the word "death" and other associations with death dominate the plot from beginning to end ([66] [all quotations were translated from the French by the author]). The land seemed to him "without a sign of life", with "a complete loneliness and sad monotony," and an ever-growing heat (pages 1,2). "How sad is this African country!" says the Spahi while walking the Saint Louis streets, "only sand and sand, there is always only this sand" (page 6). Looking from the island towards the only noticeable point on the mainland, there is the "Sor cemetery [...] where the bodies were laid, due to fevers in this horrible climate" (page 16); "a deathly silence dominates this city, fearful silence" (page 88); "It was a sad evening, in this dead quarter of the town, isolated from the dead town" (page 140).

Loti also characterised Saint Louis as "huge human antnests [...] thousands and thousands of straw-huts, Lilliputian huts with pointed roofs, where the bizarre Negro population is grouped" (page 8). Saint-Louis's streets at night, according to Loti, are deserted and dark. Moreover, the only source of light then emanated, literally, from the walls of the few solid houses: "there are, on the south of Saint-Louis, old brick houses [...] that illuminate the evening and throw over the sand trails of red light, when everyone is sleeping in the dead city" (page 18). Loti's abundant drawings assisted as well in the crystallisation of this perverse and morbid image of Africa and Senegal, yet they were only part of an entire fictional genre of exotic and escapist images originating in contemporary Europ (For a synoptic analysis of Loti's drawings see [67]. See also [68, 69]).

Contemporary maps of Saint-Louis clearly distinguish between durable premises made of bricks, and two kinds of temporary ones: regulated straw huts, on certain legallyacquired plots, and haphazardly set up straw huts, that were not recommended by the colonial administration. This distinction is exemplified, inter alia, in the legend of a map dated from 1884 (Figure 2), in which a third category, straw barracks of the Senegalese troops, is also indicated. In earlier 


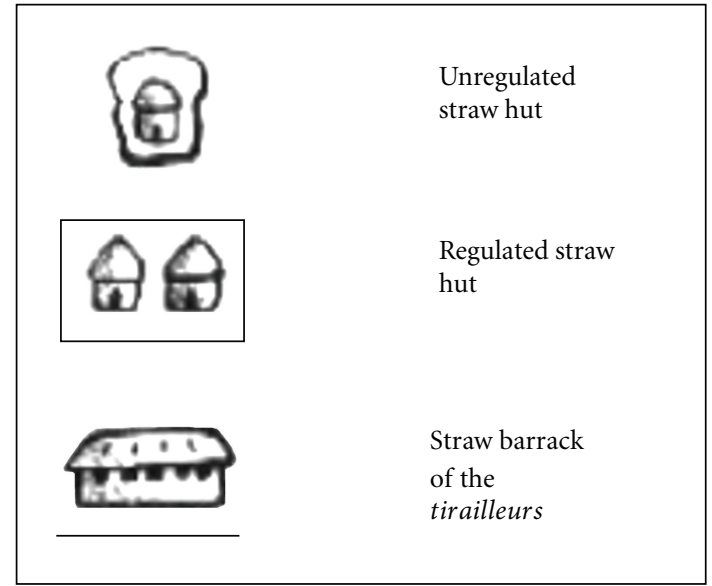

Figure 2: Extract based on Plan of Saint Louis, 1884, The British Archives, CO 700/West Africa 24. (Redrawn by the author.)

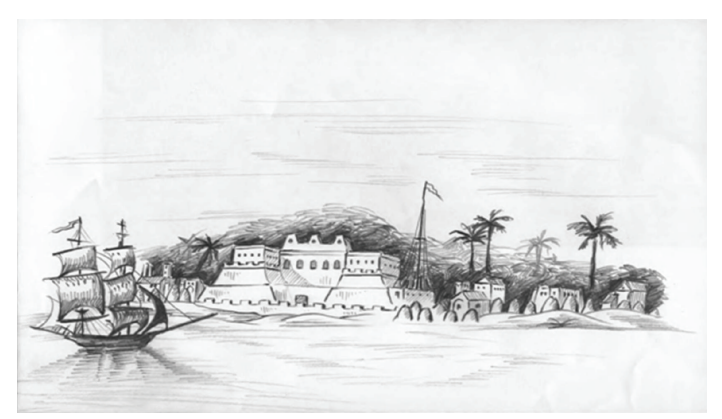

Figure 3: Part of undated engraving titled "Saint Louis côté du couchant." (Based on CAOM, FR ANOM 7 FI/33 and redrawn by the author.)

visual sources (Figure 3), durable buildings can easily be distinguished and even individually identified - for instance, the old Fort (the site of the later Government House) and the houses of the European merchants-against the mass of indigenous straw huts, generally depicted as little shacks in the foreground of the engraving.

The colonial name of the northern extension of Saint Louis, which, contrary to the settlement-proper, was mainly occupied by these huts, testified to the negative image of the straw huts. It was named "Langue de Barbarie" (i.e., Tongue of Barbary). While "Langue" referred to the sand spit, the word "Barbarie" had an ambivalent meaning. On the one hand, this extension was physically connected to the northern territories of the Moors (Maures), that is, Berberdomthe land of the Berbers of North Africa. On the other hand, "barbarie" in French (contrary to "berbère") means "roughness" or "primitiveness" (barbarism) —and this term was previously applied by the French headquarters in Gorée to the yet unexplored mainland of Dakar, as aforementioned, "terre des fièvres et de la barbarie" (indeed, an article in the Moniteur du Sénégal, 4 juillet 1865, confirms the existence of these two meanings. It deals with the inauguration of a floating bridge in Saint Louis, regarded as a demonstration of French civilisation versus local "barbarity" and as an example of the general betterment in the communication with rive des Maures, that is, "Langue de Barbarie").

The first expulsions-these affected the Lebu (Lébou) population, the original inhabitants of Cap-Vert peninsulahad indeed started with the formal occupation of Dakar, towards the end of the 1850s. The Lebu villages of Kaye and Thann were displaced to about one kilometre inland for the sake of laying the first streets, and the residents were compensated [70]. With the realisation of the 1862 master plan for the city, their counterparts of Ngaraf, Thiérigne, and Hock were also pushed in the same direction. Further displacements took place after the yellow fever epidemic of 1900. By 1905, the majority of Lebu villages had moved west of Dakar-ville, only to be pushed farther inland over the next three years [70] (Figure 4).

Many of these operations were directed by Senegal's Lieutenant Governor. In 1905, for example, he required building permission for any new structure in Dakar, which was only given where permanent building materials - that is, "en dur" - were used. Perishable materials, or anything that was not considered as en dur, included mud (known as pisé or banco in the context of the traditional building of the region), cloth, straw, tarred carton, and lattice-work. These were considered illegal in Dakar-ville from 1905 on. Outside its unofficial borders, however, in what gradually became villages (or quartiers) indigènes, regulations were less strict, and nonpermanent building materials were allowed.(For more about the pre-1914 building regulations see [71] hereafter inside [72].)

This "dual" logic perfectly coincided with colonial economic policy, which restricted investment in Dakar to the residential areas of the white minority. Thus, quite a clear differentiation between the two communities had become marked in Dakar by the 1910s, which was explained by the different "habitudes de vie," "niveaux d'éducation modern," and "différences de moeurs" [73]. Homi Bhabha will devote a chapter in one of his works to "cultural difference and colonial nonsense." (See [74]. Each cultural fixation, or naming, thus, represents the impossibility of cross-cultural identity.) yet contemporary French colonial thinking, formally at least, always avoided lingering over racial discourse. Though the latter aspect was assigned by them to the British colonial polity, careful town planning legislation, ostensibly taking into account social differences and sanitary problems, assisted in creating de facto system of racial segregation on the French side. Though these pre-1914 displacements in Dakar were characterised as being small-scale and unsystematic, the idea of residential segregation there was always present. One of the reasons that prevented the French colonial authorities from enforcing, a wholesale residential segregation in Dakar on a legislative basis was the political status of the city. This status, particular to the French regime in West Africa, would make segregation an embarrassing issue.

From 1887 on, Dakar was considered one of the Quatre Communes, the Four Communes of Senegal, following SaintLouis, Gorée, and Rufisque. (Each of these communes was entitled to a council, elected by its adult males, and a mayor as its president. All the indigenous inhabitants who were born in these urban settlements or lived there for more than five years were regarded as French citizens and legally 


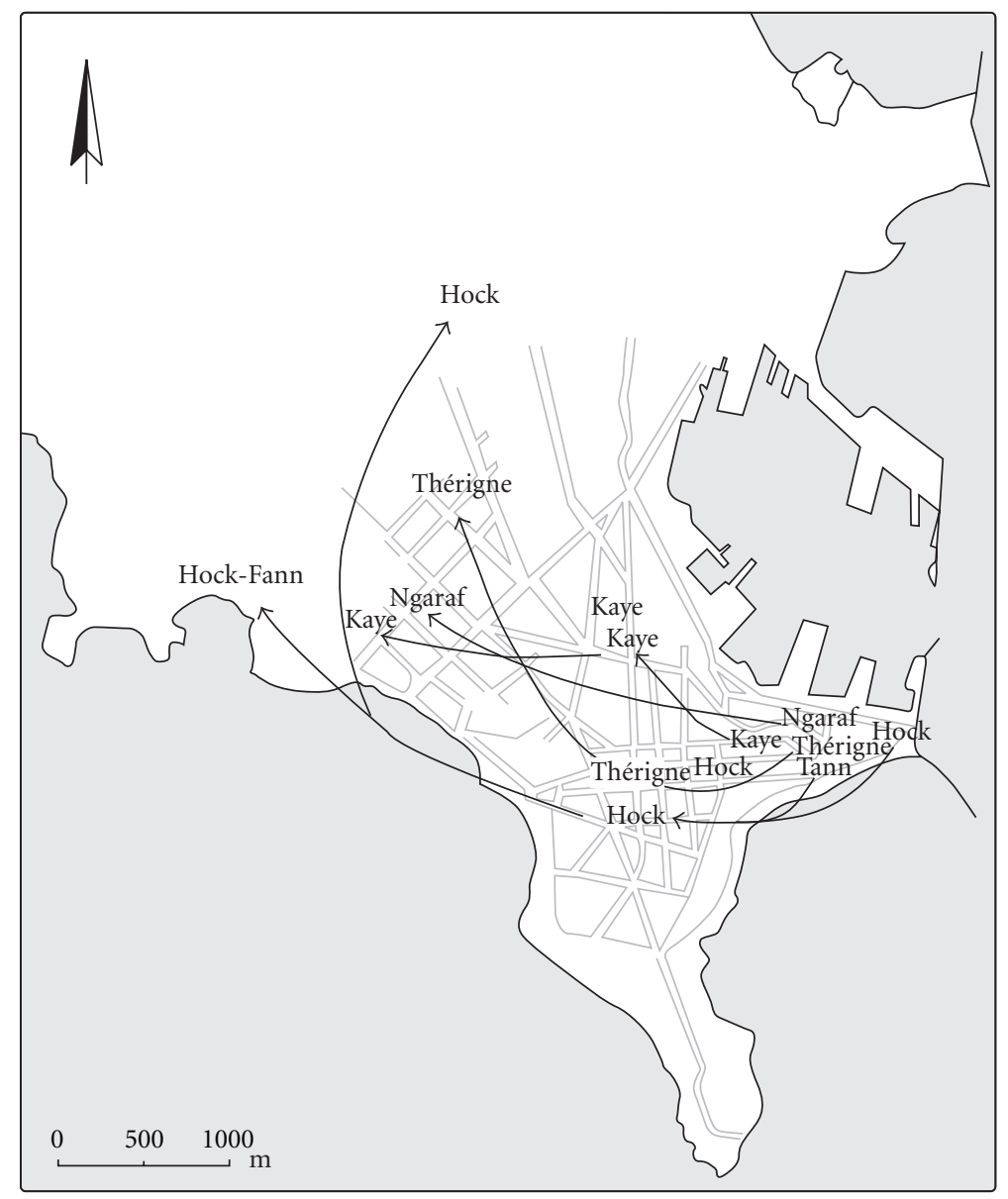

FIGURE 4: The displacement of the Lebu residential quarters from the city centre of colonial Dakar by the 1910s. (Map based on Seck's Dakar [1970], redrawn by the author).

enjoyed political rights similar to those of all Frenchmen. They were called originaires and could elect one deputy to the French parliament. As citoyens of the Communes, they were distinct from the sujets, that is, the other inhabitants of the AOF (see note 38 ) region. The sujets-the large majority in the colonial territory, which was mostly rural-were subject to the juridical system of the indigénat, which meant, for example, a conscription for forced labour and military service [75]. See also [76]) (Figure 1). The Four Communes were considered exemplary cases of the then French colonial doctrine of assimilation. Generally speaking, the aim of this doctrine, as asserted by the Third Republic, was to turn the colony into an integral part of the mother country, and its population was to be considered equal as far as possible to that of the mother country. The sixth paragraph of the third constitution of 1795 labelled the colonies as inseparable parts of the Republic, subjected them to the same laws, and clarified French colonial ideals and concepts such as France d'outre mer or la plus grande France ([77] (page 166). For more about the assimilation, see $[78,79])$. At the heart of this attitude to the colonies lay the idea of human equality, which was inherent in the Revolution, and the belief that French culture, together with its mission civilisatrice, was not inferior to any other culture, to say the least. In line with this concept,
Algeria was considered nothing less than an extension of France since 1871, following the completion of the French conquest, and Dakar too was proclaimed by the Colonial Congress of 1889 a distant suburb of Paris [80]. However, the fact that Dakar became the headquarters and the capital of the AOF federation in 1902 complicated any realisation of residential segregation on a formal basis, which now became an uncomfortable if not illegal idea. (The AOF (Afrique Occidentale Française or French West Africa) was created in 1895, alongside of the neighbouring (later) federation of French Equatorial Africa (AEF). The aim was to facilitate the centralist decision-making process in Paris. The AOF's overall territory amounted to 4,633,985 square kilometres and included eight colonies: Senegal, French Sudan (today's Mali), French Guinea, Ivory Coast, Dahomey (today's Benin), Upper Volta (today's Burkina Faso), Niger, and Mauritania [81]).

Indeed, dramatic changes took place in colonial urban Dakar that intensified immigration to the city, both African and European. With the initiation of the Dakar-Saint Louis railway in 1885, the improvement of the city's deep water port, and the transfer of the capital city of French West Africa (AOF) from Saint Louis to Dakar in 1902,_-it is possible to say that the city entered its "imperial" phase. The first years after 1902 in Dakar, therefore, witnessed a reorganisation of 


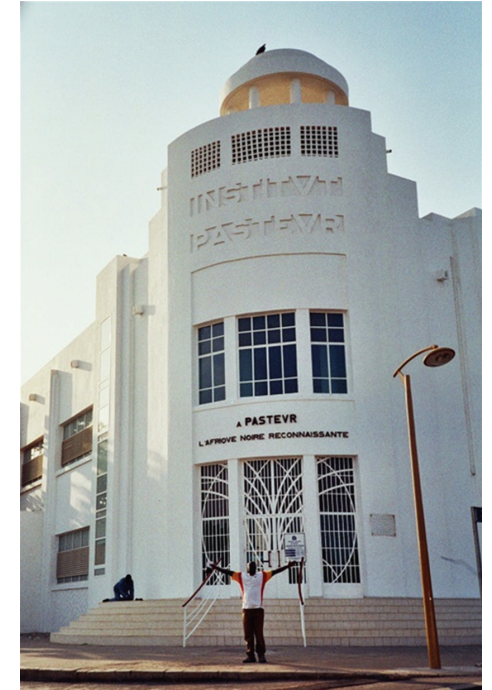

Figure 5: Pasteur Institute, Dakar, 1937. (Photograph by the author).

the federation under the Governor, General Ernest Roume. In trying to combat outbreaks of infectious diseases, Roume launched a unified programme of public health and public work policy, carried out in the assimilative spirit. The British colonial regime in West Africa by contrast never professed extending London to Lagos, or carrying out such ambitious plans of social engineering. But there is also no reason to believe that Dakar really became a twin of Paris, nor even its twin-to-be. In reality, for instance, on the eve of the First World War there were still only about one hundred European doctors for a French-ruled African population of around ten million [82].

Moreover, while the famous Pasteur Institute and its overseas network were tightly bound to French national pride and colonialist lobbies, most of the branches, especially in Africa, had no more than one or two workers with appropriate medical qualifications. (For more about the French scientific imperialism, the colonial endeavour, and the Pasteur Institute, see [83].) The Institute in Paris kept close scientific control over the new branches, yet was reluctant to legitimise them. For instance, the microbiological laboratory of Saint-Louis in Senegal was established about a decade after the Institute in France, in 1896; it was transferred to Dakar in 1913, but was not officially recognised until 1924. In Dakar, it was housed for a long time in dilapidated buildings and only moved to a better accommodation, thanks to a loan, in March 1937. Though the Senegalese Institute could enlarge its staff and raise funds for research of epidemic diseases-we shall not evaluate here the work of the Pasteurians in tropical medicine-its activity was often encumbered by colonial bureaucracy and interests (for the Pasteur Institutes in Africa (Brazzaville, Kindia, Bamako and Dakar), see [84]. For more details about the extent of funds for yellow fever research that were allocated for Dakar by comparison to other French colonial towns in West Africa, see [85]) (Figure 5).

Colonial sanitary reforms were directly related to other projects of urban development, such as the establishment of Dakar's main streets-usually tree-lined and twenty metre wide. But the colonial authorities regarded these projects as part of the sanitary debate and its famous policy of "assainissement" (development according to health standards), rather than as part of the urban debate as such. Consequently, the establishment of the first main roads of Dakar was regularly classified in the official documentary records less as "urban planning" than as "assainissement," changing street names only within the framework of this classification (see, for instance, [86]).

The experience with Dakar's Médina in the early twentieth century shows that improving urban sanitation was not realised by the introduction of mass medicine, but by introducing residential segregation. At the same time, the French authorities never felt committed, either economically or emotionally, to the segregationist project there, which also languished because of local and international politics.

\section{The 1914 Bubonic Plague and the Establishment of Dakar's Médina}

Between 1894 and 1914, a wave of bubonic plague epidemics spread across the world, by way of sea routes that had been created by the European forces. From Australia to South Africa, it finally reached northern Africa, after hitting GrandBassam (Ivory Coast), Accra, and Dakar. The number of dead in Dakar during the plague, which began in April 1914 and ended in January 1915, was 3,653, out of a total population of 26,000 ([4] (page 13)). In the first weeks following the outbreak, the idea of complete separation between what was gradually to become the quartier indigène and Dakarville was still not apparent. Yet harsh measures were taken. These included burnings of huts, along with the formation of quarantine camps and vaccination of the population. The population of Dakar tended not to cooperate, and these measures were administered by force with the help of the police. ([4]. Sanitary measures met opposition in the metropole as well. For popular resistance to the apparatus set up to fight the cholera epidemic in 1832 Paris, which was backed by the police, see $[3,40]$.)

In addition, two sanitary belts were established in Dakar at this stage. The first cordon sanitaire was established inside the colonial city centre, along the wide avenues. It served as a barrier between Dakar-ville and the quartiers indigènes to its west. This cordon, however, eventually proved to be short lived and was almost immediately annulled. While Europeans were permitted to move freely everywhere, Africans, especially those employees who were considered "vital" for Dakar's "material life", were obliged to carry a Pass (indeed the "pass", given to vaccinated Dakarois, tended to be shared by everyone who wished to travel out of the city) [87]. This interrupted the commercial life of the city and seemed unfit for the prevention of the spread of the plague.

The second cordon sanitaire was less temporary. It stretched between the village of Hann, at the northern edge of Dakar towards the city itself (Dakar-ville), and was intended to prevent the disease from spreading to the rest of the colony. It was 900 metres wide, and no building or free 
movement were permitted on it, apart from the colonial Senegalese forces (tirailleurs), who went on horseback (For the two cordons, see $[88,89])$. This belt, as implied by later commentators and maps of Dakar, actually served as a barrier between Dakar-ville and the Médina-to-be well after the 1914 plague. Derwent Whittlesey, for example, a visitor in Dakar in 1941, mentioned a 900-metre belt void of buildings that still separated these two areas, and only contained a racecourse and a stadium ([90] (page 631)). This area is also clearly shown on maps of Dakar of the 1920s, with a Champ de Courses between Dakar-ville and the Médina; by 1957, on the eve of independence, this area had been kept relatively vacant, confined to several public institutions.

Returning to 1914 Dakar, in July, three months after the outbreak of the plague, several ordinances issued by the Lieutenant Governor of Senegal enforced severe rules regarding construction and the salubrity of houses. All thatched huts in the area stretching from the then Avenue Gambetta eastwards to the sea had to be demolished, while permanent structures had to be fumigated [91]. Plots were offered in a newly established ville indigène to those who could not afford or did not want to build en dur. There, in order to attract Africans, laws regarding land-use were lax in comparison with Dakarville, now designated for Europeans. Indeed one of the considerations of the creation of the ville indigène was the cost of compensation for re-erecting the burnt-out huts in Dakar-ville [91]. The colonial administration provided straw for the building of residents in the Médina, low cost standard structures made of wooden beams and bricks, for those who wished and could afford to build permanently. In practice, most of the residential units in the Médina in the immediate period after its creation were made of wooden beams [92].

Owing to the severity of the situation, these ordinances were quickly applied. By August, the proposed new residential quarter had been defined geographically-north-west of the older sections of Dakar. In the following months, a few thousand Africans were transferred to the area, originally named "village de segregation." Ironically, the then GovernorGeneral thought that this name might mislead the indigenous population. It implied that these people, transferred there after few days of enforced isolation for medical reasons, were still contaminated. Moreover, it created the wrong impression that the transfer to the "segregation village" was temporary, or that the building regulations there would be too rigid [93].

This "village"-the name also clarifies that at this early stage the quarter was not perceived as a real part of the "city" —was named Médina (or La Médine), as inspired by the French experience in North Africa. There both notions médina and casbah equally refer to the medieval heart of the Muslim city, save for Rabat, Morocco, where the casbah had a different sociopolitical orientation, and was on higherground and older than the post-1610s médina [94]. The meaning of the word médina in Arabic is "town" or "dwelling place," but in the colonial context it was used to designate the living quarters of the "natives," whether the old Muslims of North Africa or those of the newly created Dakar counterpart (This argument was inspired by [95]). The long-standing presence of Islam in the AOF colonies, since the eleventh

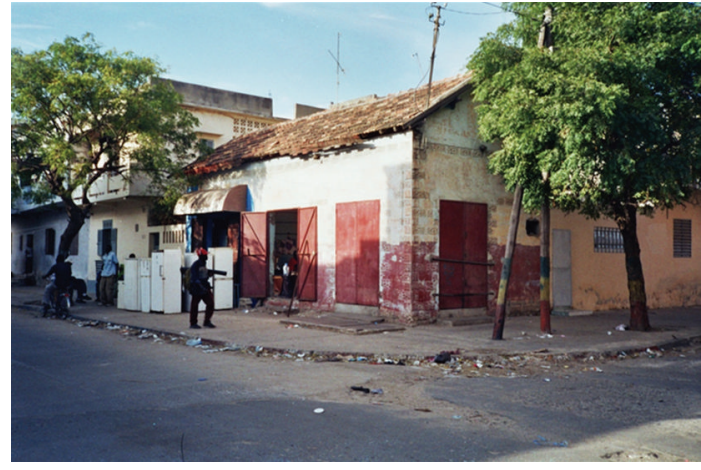

FIgURE 6: Street in today's Médina. (Photograph by the author).

century, and the fact that the great majority of the AOF population was Muslim, may explain the "borrowing" of this notion. The local name for this quarter in Dakar, however, was Tilène, which means in Wolof "a region visited by jackals [96]."

The sandy, infertile, and relatively low terrain of the Médina tended to flooded a great deal in the rainy season; both brackish water and high population density there were sources of illness in themselves. Minimal infrastructure was only laid at the end of the 1920s and was further developed, at intervals, until the 1950s. It included most basic projects, such as open sewers, water pumps, some lighting and asphalt roads, as well as modest public constructions, such as a market, a mosque, and a caravanserai [97-101]. The grid plan of the Médina, the first example of systematic indigenous settlement in Senegal, was also a means of government security. It facilitated recapturing deserters from forced labour and military service. And, as often recalled by a director of Public Works in the AOF, a single armoured car placed at an intersection could control the entire length of two streets. (As noted (with no further reference) [102] (page 30)) (Figure 6).

It is noteworthy that the regulated, grid plan of this entirely French creation of Dakar's Médina was the very opposite of the intricate texture of the Islamic médinas of North Africa. The latter have closed, inward-facing residential units ending in cul-de-sacs, with small entrances from a divider street, and with a few throughstreets. The layout of Algiers' médina, for example, was referred to during the first stages of the consolidation of French rule there as a "capricious" and "chaotic," a "problem" that should be solved [45]. And, these peculiar characteristics turned it, about a hundred years later, into a central arena for fighting against the colonial forces. As for Dakar, the poor conditions of its Médina were not the cause of the fact that by that time only 8,000 Dakarois were living in the Médina, while 20,000 were still living in Dakar-ville, most of them in substandard houses [3].

The fact that a considerable portion of Dakarois was actually left in Dakar-ville is clearly noticeable in aerial photos of Dakar-ville taken after the Médina's establishment. (For the aerial photos see [103].) These indicate that many subunits and Lebu compounds were moulded into the 


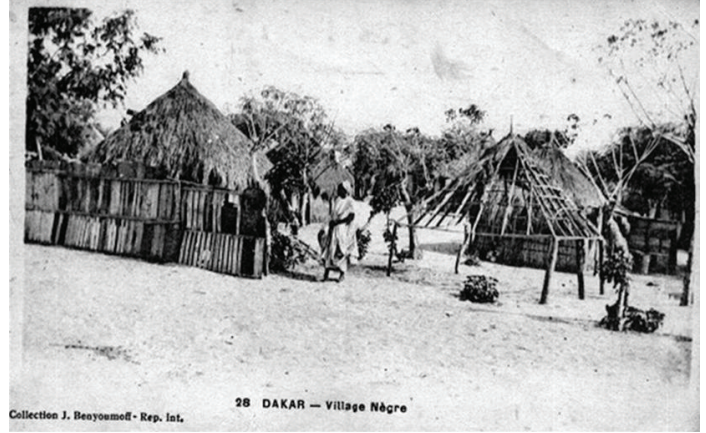

Figure 7: Photo of Lebu huts in 1910s Dakar. (Postcard, private collection).

iron-grid plan of Dakar's city centre. Each compound was composed of several groups of round (and later rectangular) huts. This organisation, which originated in precolonial forms, was now traversed by the Western iron-grid system of broad, straight streets. Figure 7 for instance, shows that the Lebu compounds were situated in Dakar-ville or at its margins were arranged in conformity with the overall orthogonal plan. It was taken in the 1910s by Jean Benyoumoff-a French commercial photographer and publisher who was then active in Senegal, whose images depict both local and colonial cultures in a picturesque, orientalist manner.

Contemporary written sources complement this visual evidence. An official survey on the subject of public hygiene from 1920, about five years after the Médina's establishment, shows the Lebu enclaves that were still left in Dakar-ville, by name. It comprises a list prepared for the benefit of the relevant European staff, such as doctors and sanitarians, who came in direct contact with the African residents of the colonial centre of Dakar. The list was made according to the local name of the area (a name of a village and/or a lineage), its borders (as defined by the French street naming system), and its ethnic affiliation. One example, out of the thirteen such areas which were identified by the survey, is "Dieko/Comprised within Rue de Thiès, Rue Sandiniéry, Rue Blanchot, Avenue Gambetta/Occupied by Lebus [104] (Table 1)." This is an outstanding testimony of the colonial situation in which the authorities in Dakar were forced to accept compromises - in terms of both Lebu urban terminology and their presence in Dakar-ville, in what was considered by them as "our streets and our boulevards (Cited in [105]).

Indeed, the majority of the Bambara and Toucolour residents of Dakar were transferred to the Médina in the summer of 1914, but this was not the case with the Lebu. The latter, being the original population of Cap Vert, had already been the main sufferers from colonial land policy, subsequent to the realisation of the 1862 colonial plan for Dakar. Further expropriations took place when Lebu landowners of confiscated terrains in the Médina-to-be area had been obliged by the colonial Court to accept compensation that was considerably lower than that initially offered. They regarded the small amounts of money as a bribe, yet their appeals were dismissed since submitted "too late." (The land
TABLE 1: Part of the official survey showing the local Lebu names, which were assigned to their residential areas within the centre of Dakar by 1920. (Based on ANS, H22).

\begin{tabular}{lll}
\hline Quarter of & Comprised within & Occupied by \\
\hline \multirow{2}{*}{ Tiédème } & $\begin{array}{l}\text { Jauréguiberry Avenue } \\
\text { Thiong Street } \\
\end{array}$ & Lebu \\
& Paul Holle Street & \\
S'bot & Boulevard National & Lebu \\
& Gambetta Avenue & \\
& Blanchot Street & \\
\hline \multirow{3}{*}{ N'Graff } & Faidherbe Avenue & \\
& Thiès Street & Few Lebu and \\
& Raffenel Street & many strangers \\
& Blanchot Street & \\
\hline
\end{tabular}

question was in fact left unsolved until the independence era. About the Lebu interpretations and feelings until pre1914 Cap Vert, see [106]. For full details on the 1914 expropriations see $[107,108]$.

Emotions ran high. The demolition of huts and the refusal of the hated Conseil d'hygiène to return the bodies of the infected for burial in accordance with Muslim rites, caused anger. So was their belief that the authorities were collaborating with local French merchants, who would benefit from the sale of building materials imposed by the new sanitary regulations [3]. The Lebu thus refused to sell food in the markets of Dakar to the whites and their servants. This Lebu market-based boycott can be regarded as a typical form of expression of sociopolitical discomfort. As noted by Catherine Coquery-Vidrovitch, Marxist in her analysis, it was one of the first boycotts in the pre-First World War political history of West Africa, somewhere between a strike and a revolt ([109] (page 493)).

Moreover, the sanitary issue became immediately confused with the political one, as Blaise Diagne had been elected as the first black African deputy to the French parliament one day after the official announcement of Dakar as plagueaffected. The position of Diagne was equal to William Ponty's, the Governor General of the AOF. Yet both, acting in a broader political sphere, had to mediate between the two opposing groups. That is, hundreds of angry Lebu on the verge of violent struggle, on the one side, and the local French and métis community, represented by the municipality, who fostered residential segregation, on the other [3]. Other incidents, such as the call of the then Mayor of Dakar, himself a métis - "Go ahead, dirty blacks, tell your deputy to come to stop us from burning down your huts" (Quoted from [110])-reflected the complexity of the situation.

The reason Diagne, however, did not support the French sanitary policies was French patriotism. On the eve of the First World War, his support for the campaign to recruit more tirailleurs for the French army was vital. In return, his demand for improvement of the conditions of African soldiers, both in the AOF and abroad, had to be met. As 
a result, by the end of the war, Diagne had acquired a reputation as a spokesman for the rights of all Africans against a demanding colonial regime ([3]. See also [111]). Ponty, for his part, was cautioned by the Minister of the Colonies in Paris that any bloody incident with the Lebu would most probably be manipulated by the Germans and Turks in order to agitate the Muslims in the colonies against France. Ponty, therefore, stopped hut demolitions, and the transfer to the Médina was delayed. (For more about the positions of Ponty and Diagne, see [112]. See also [3]. A considerable part of Echenberg's recent study deals with the 1914 epidemic and covers very thoroughly these critical days in Dakar. Though it touches issues of residential policies, its analysis of the sociopolitical aspects of the plague is most comprehensive [5].) Some twenty years later, the Public Works Department of the AOF reflected with much dissatisfaction upon the unaccomplished segregation project in Dakar. According to the Department, as mentioned above, more than 20,000 natives, mostly Lebu, were still living in Dakar-ville on land they refused to sell, and their "dilapidated" straw huts were rented at rather high rates to thousands of African immigrants. (Inspection Générale des [113] (page 154).)

\section{Conclusion}

The politics and policies of "assainissement" in the colonial urban context were not merely a welfare project, motivated by purely public hygiene objectives. Facing health hazards that haunted the West African coast, early twentieth century French colonial urban policies were marked by internal conflicts and oscillated between two main ends. The first was a preference for sanitary measures that were temporary yet immediate and severe against specific indigenous groups, as recommended by the medical authorities. The second purpose was the use of plagues as a means of establishing a "final solution" to the question of cohabitation, thereby fostering residential segregation. Through the examination of these opposing forces within the community of the colonisers, it is shown here that various indigenous forces also had a considerable role in the extent of the actual realisation of colonial residential policies, through direct and indirect responses to sanitary reforms. Consequently, the wide gap between colonial desires and the African reality is stressed, as well as the gap between theory and eventual practice, between the doctrinal and the practical, the intended, and the achievable. The main cause of the partial victory of the local agencies concerning Dakar's assainissement was the budgetary constraints of the colonial state. The consequent strength-cum-weakness of the latter led it first to try to establish a clear residential separation between the two main communities, and then to fail in practice.

Senegal's colonial urban sphere was not exceptional in using pseudomedical explanations for creating residential segregation. Segregationist policies, accompanied by sanitary arguments, were in fact an integral feature in both the determination and planning of the colonial city in general-be it French, British, Belgian, or other. Yet what was essentially characteristic of policies of residential segregation in the French colonies in Africa was the fact that (a) their racial reasoning was never overt-it was masked by cultural explanations, such as different "habitudes de vie", "niveaux d'éducation modern," and "différences de moeurs" and (b) they never had a formal legislative basis directly related to racial differences. It was not "apartheid" per se, of course, and also not the one exemplified, for instance, in Lord Lugard's Township Ordinance of 1917, enforcing a colour bar in the colonial urban sphere of British Nigeria [114]. The French colonial authorities always criticised their British counterparts on this issue, arguing, as with the establishment of Dakar's Médina, that it was not a racial segregation between two kinds of people, but a segregation between two kinds of residential forms. That is, between permanent building using bricks in accordance with the sanitary regulations and temporary building using other, substandard, materials that constituted a health hazard [115]. Yet segregation on medical or pseudosanitary grounds could easily bring forth a "dual city" policy of racial segregation.

\section{References}

[1] A. Seck, Dakar, Métropole OuestAfricaine, IFAN, Dakar, Senegal, 1970.

[2] B. Salleras, La peste à Dakar en 1914: médina ou les enjeux complexes d'un politique sanitaire, unpublished $\mathrm{Ph} . \mathrm{D}$. thesis, EHSS, Paris, France, 1984.

[3] R. Betts, "The establishment of the medina in Dakar, Senegal, 1914," Africa, vol. 41, pp. 143-152, 1971.

[4] E. M'Bokolo, "Peste et société urbaine à Dakar: l'épidémie de 1914," Cahiers d'Études Africaines, vol. 12, no. 1-2, pp. 13-46, 1982.

[5] M. Echenberg, Black Death, White Medicine: Bubonic Plague and the Politics of Public Health in Colonial Senegal, 19141945, Heinemann, Portsmouth, NH, USA, 2002.

[6] G. W. Hartwig and D. K. Patterson, Eds., Disease in African History, Duke University Press, Durham, NC, USA, 1978.

[7] M. Vaughan, Curing Their Ills: Colonial Power and African Illness, Cambridge, UK, Polity Press, 1991.

[8] M. Lyons, The Colonial Disease: Social History of Sleeping Sickness in Northern Zaire, 1900-1940, Cambridge University Press, Cambridge, UK, 1992.

[9] P. D. Curtin, Death by Migration: Europe's Encounter with the Tropical World in the Nineteenth Century, Cambridge University Press, Cambridge, UK, 1995.

[10] P. D. Curtin., Disease and Empire: The Health of European Troops in the Conquest of Africa, Cambridge University Press, Cambridge, UK, 1998.

[11] F. Cooper, From Slaves to Squatters: Plantation Labor and Agriculture in Zanzibar and Coastal Kenya, 1890-1925, Yale University Press, New Haven, Conn, USA, 1980.

[12] F. Cooper, Decolonization and African Society: The Labor Question in French and British Africa, Cambridge University Press, Cambridge, UK, 1996.

[13] L. White, The Comfort of Home: Prostitution in Colonial Nairobi, University of Chicago Press, Chicago, Ill, USA, 1990.

[14] C. van Onselen, Studies in the Social and Economic History of the Witwatersrand, 1886-1914, Ravan, Johannesburg, South Africa, 1982. 
[15] J. Parker, Making the Town: Ga State and Society in Early Colonial Accra, Heinemann, Portsmouth, NH, USA, 2000.

[16] P. Maylam, "Explaining the apartheid city: 20 years of South African urban historiography," Journal of Southern African Studies, vol. 21, no. 1, pp. 19-38, 1995.

[17] C. Coquery-Vidrovitch, "The process of urbanization in Africa (from its origins to the beginning of independence)," African Studies Review, vol. 34, no. 1, pp. 1-98, 1991.

[18] D. Anderson and R. Rathbone, Eds., Africa's Urban Past, James Currey, Oxford, UK, 2000.

[19] S. J. Salm and T. Falola (eds.), Eds., African Urban Spaces in Historical Perspective, University of Rochester Press, Rochester, NY, USA, 2005.

[20] M. Culot and J.-M. Thiveaud, Eds., Architecture Française outre mer, Pierre Mardaga, Liège, Belgium, 1992.

[21] A. Sinou, Comptoirs et Villes Colonials du Sénégal: SaintLouis, Gorée, Dakar, Karthala, ORSTOM, Paris, France, 1993.

[22] J. Soulillou, Ed., Rives Colonials: Architecture de Saint-Louis à Douala, Parenthèses, Paris, France, 1993.

[23] O. Goerg, Pouvoir Colonial, Municipalités et Espaces Urbains: Conakry-Freetown des Années 1880-1914, l'Harmattan, Paris, France, 1997.

[24] R. Home, Of Planting and Planning: The Making of British Colonial Cities, E \& FN Spon, London, UK, 1997.

[25] L. Fourchard, De la Ville Coloniale a la Cour Africaine: Espaces, Pouvoirs et Sociétés a Ouagadougou et a Bobo-Dioulasso (Haute Volta), l'Harmattan, Paris, France, 2001.

[26] M. Crinson, Modern Architecture and the End of Empire, Ashgate, Aldershot, UK, 2003.

[27] G. A. Myers, Verandahs of Power: Colonialism and Space in Urban Africa, Syracuse University Press, New York, NY, USA, 2003.

[28] C. Coquery-Vidrovitch, The History of African Cities South of the Sahara: From the Origins to Colonization, Markus Wiener Publishers, Princeton, NJ, USA, 2005.

[29] Institut National du Patrimoine, Architecture Coloniale et Patrimoine: L'expérience Française, Somogy, Paris, France, 2005.

[30] L. Bigon, A History of Urban Planning in Two West African Colonial Capitals: Residential Segregation in British Lagos and French Dakar (1850-1930), Mellen Press, Lewiston, Me, USA, 2009.

[31] B. Toulier, J. Lagae, and M. Gemoets, Kinshasa. Architecture et Paysage Urbains, Somogy, Paris, France, 2010.

[32] A. D. King, Colonial Urban Development: Culture, Social Power and Environment, Routledge, London, UK, 1976.

[33] P. Curtin, "Medical knowledge and urban planning in tropical africa," American Historical Review, vol. 90, no. 3, pp. 594-613, 1985.

[34] A. D. King, The Bungalow: The Production of a Global Culture, Oxford University Press, Oxford, UK, 1995.

[35] J. Jacobs, Edge of Empire: Post Colonialism and the City, Routledge, London, UK, 1996.

[36] B. Yeoh, Contesting Space: Power and the Built Environment in Colonial Singapore, Oxford University Press, Oxford, UK, 1996.

[37] J. Hosagrahar, Indigenous Modernities: Negotiating Architecture and Urbanism, Routledge, New York, NY, USA, 2005.

[38] J. L. Abu-Lughod, Rabat: Urban Apartheid in Morocco, Princeton University Press, Princeton, NJ, USA, 1980.

[39] S. Dubow, Racial Segregation and the Origins of Apartheid in South Africa, 1919-36, St. Martin's Press, New York, NY, UK, 1989.
[40] P. Rabinow, French Modern: Norms and Forms of the Social Environment, MIT Press, Cambridge, UK, 1989.

[41] D. Prochaska, Making Algeria French: Colonialism in Bône, 1870-1920, Cambridge University Press, Cambridge, UK, 1990.

[42] G. Wright, The Politics of Design in French Colonial Urbanism, The University of Chicago Press, Chicago, Ill, USA, 1991.

[43] N. AlSayyad, Ed., Forms of Dominance: On the Architecture and Urbanism of the Colonial Enterprise, Avebury, Aldershot, UK, 1992.

[44] S. Dubow and W. Beinart, Eds., Segregation and Apartheid in Twentieth-Century South Africa, Routhledge, New York, NY, UK, 1995.

[45] Z. Çelik, Urban Forms and Colonial Confrontations: Algiers Under French Rule, University of California Press, Berkeley, Calif, USA, 1997.

[46] J. Nasr and M. Volait, Eds., Urbanism: Imported or Exported? Wiley \& Sons, Chichester, UK, 2003.

[47] M. W. Swanson, "The sanitation syndrome: bubonic plague and urban native policy in the cape colony, 1900-1909," Journal of African History, vol. 18, no. 3, pp. 387-410, 1977.

[48] R. Home, "Town planning, segregation and indirect rule in colonial Nigeria," Third World Planning Review, vol. 5, no. 2, pp. 165-175, 1983.

[49] J. Robinson, "A perfect system of control? State power and "Native Locations" in South Africa," Environment and Planning, vol. 8, no. 2, pp. 135-162, 1990.

[50] L. Fourchard, "Propriétaires et commerçants africains à Ouagadougou et à Bobo-Dioulasso (Haute-Volta) fin $19^{\text {ème }}$ siècle-1960," Journal of African History, vol. 44, no. 3, pp. 433-461, 2003.

[51] M. Foucault, Discipline and Punish: The Birth of the Prison, Penguin, Harmondsworth, UK, 1977.

[52] M. Foucault, Power/Knowledge: Selected Interviews and Other Writings, Harvester Press, Brighton, UK, 1980.

[53] B. S. A. Yeoh, Contesting Space: Power Relations and the Urban Built Environment in Colonial Singapore, Oxford University Press, Oxford, UK, 1996.

[54] Santelli, Quelques considérations médicales sur le poste de Dakar, Sénégal, thèse en médcine, Imprimerie Cantrale du Midi, Montpellier, France, 1877.

[55] A. Sinou, "La Sénégal," in Rives Coloniales: Architectures de Saint Louis à Douala, J. Soulillou, Ed., pp. 31-62, ORSTOM, Paris, France, 1993.

[56] P. D. Curtin, Death by Migration: Europe's Encounter with the Tropical World in the Nineteenth Century, Cambridge University Press, Cambridge, UK, 1995.

[57] CAOM, FM SG, and SEN XII, "129: création d'un point d'appui de la flotte à Dakar,” 1900.

[58] CAOM, FM SG, and SEN XII, "110: note sur la salubrité de Dakar et sur les moyens préconisés pour l'améliorer," 1900.

[59] G. Ribot and R. Lafon, Dakar: Ses Origins, son Avenir, Larose, Paris, France, 1908.

[60] CAOM, FM SG, and SEN XII, "50: etat sanitaire de l'Afrique Occidentale, Companie Française de l'Afrique Occidentale," 1900.

[61] A. Sinou, in Comptoirs et Villes Colonials du Sénégal: SaintLouis, Gorée, Dakar, pp. 189-190, Paris, France, Karthala, ORSTOM, 1993.

[62] A. Sinou, in Comptoirs et Villes Colonials du Sénégal: SaintLouis, Gorée, Dakar, pp. 158-159, Paris, France, Karthala, ORSTOM, 1993. 
[63] A. Sinou, in Comptoirs et Villes Colonials du Sénégal: Saint-Louis, Gorée, Dakar, p. 161, Paris, France, Karthala, ORSTOM, 1993.

[64] 1937, The Mayor of Saint-Louis: Paul Vidal, 'Incendies à Guet N'Dar', Le periscope Africaine.

[65] A. Sinou, in Comptoirs et Villes Colonials du Sénégal: Saint-Louis, Gorée, Dakar, p. 208, Paris, France, Karthala, ORSTOM, 1993.

[66] Pierre Loti, Le Roman d'un Spahi, Calmann-Lévy, Paris, France, 1896.

[67] C. Farrère, Cent Dessins de Pierre Loti, Tours, Arrault, 1948.

[68] E. C. Nwezeh, Africa in French and German Fiction, 19111933, University of Ife Press, Ibadan, Nigeria, 1978.

[69] T. Todorov, On Human Diversity: Nationalism, Racism and Exoticism in French Thought, Harvard University Press, Cambridge, UK, 1993.

[70] A. Seck, in Dakar, Métropole Ouest Africaine, p. 129, IFAN, Dakar, Senegal, 1970.

[71] ANS, H22, l'Hygiène à Dakar, 1919-1920 (Rapport sur l'hygiène à Dakar de 1899-1920), pp. 354-355.

[72] A. Seck, in Dakar, Métropole Ouest Africaine, p. 133, IFAN, Dakar, Senegal, 1970.

[73] A. Sinou, in Comptoirs et Villes Colonials du Sénégal: SaintLouis, Gorée, Dakar, pp. 193-194, Paris, France, Karthala, ORSTOM, 1993.

[74] H. K. Bhabha, The Location of Culture, Routledge, London, UK, 1994.

[75] A. F. Clark and L. C. Phillips, Historical Dictionary of Senegal, The Scarecrow Press, London, UK, 1994.

[76] W. Johnson, The Emergence of Black Politics in Senegal: The Struggle for Power in the Four Communes, 1900-1920, Stanford University Press, Stanford, Calif, USA, 1971.

[77] M. D. Lewis, "One hundred million frenchmen: the assimilation theory in French colonial policy," in Problems in the History of Colonial Africa, 1860-1960, R. O. Collins, Ed., Prentice Hall, Englewood Cliffs, NJ, USA, 1970.

[78] R. F. Betts, Assimilation and Association in French Colonial Theory, 1890-1914, Columbia University Press, New York, NY, USA, 1961.

[79] A. L. Conklin, “Democracy' rediscovered, civilisation through association in French West Africa, 1914-1930," Cahiers d'Etudes Africaines, vol. 37, no. 1, pp. 59-84, 1997.

[80] R. F. Betts, in Assimilation and Association in French Colonial Theory, 1890-1914, pp. 13-31, Columbia University Press, New York, NY, USA, 1961.

[81] J. Suret-Canale, French Colonialism in Tropical Africa, 19001945, PICA Press, New York, NY, USA, 1971.

[82] C. Coquery-Vidrovitch and O. Goerg, l'Afrique Occidentale au Temps des Française, La Découverte, Paris, France, 1992.

[83] A. M. Moulin, "Patriarchal science: the network of the overseas pasteur institutes," in Science and Empires: Historical Studies about Scientific Development and European Expansion, P. Petitjean, C. Jami, and A. M. Moulin, Eds., pp. 307-321, Kluwer, Boston, Mass, USA, 1992.

[84] J. Suret-Canale, in French Colonialism in Tropical Africa, 1900-1945, pp. 404-406, PICA Press, New York, NY, USA, 1971.

[85] CAOM, FM SG, and SEN XI, "50: police, hygiene et assistance, fièvre jaune, 1895-1904”.

[86] ANS, P 168: Assainissement et urbanisme de Dakar: travaux de l'avenue des Madeleines, 1905-1913.

[87] ANS, "H55: peste à Dakar," 1914.

[88] ANS, P 190: Assainissement et urbanisme de Dakar, village de Médina, création de village, 1915-1919.
[89] B. Salleras, La peste à Dakar en 1914: médina ou les enjeux complexes d'un politique sanitaire, unpublished $\mathrm{Ph} . \mathrm{D}$. thesis, EHSS, Paris, France, 1984.

[90] D. Whittlesey, "Dakar and other cape verde settlements," Geographical Review, vol. 31, no. 4, pp. 609-638, 1941.

[91] A. Seck, in Dakar, Métropole Ouest Africaine, p. 134, IFAN, Dakar, Senegal, 1970.

[92] ANS, H22, l'Hygiène à Dakar, 1919-1920 (Rapport sur l'hygiène à Dakar de 1899-1920).

[93] ANS, "H55: peste à Dakar," 1914.

[94] J. L. Abu-Lughod, in Rabat: Urban Apartheid in Morocco, pp. 63-67, Princeton University Press, Princeton, NJ, USA, 1980.

[95] A. Sinou, in Comptoirs et Villes Colonials du Sénégal: Saint-Louis, Gorée, Dakar, p. 281, Paris, France, Karthala, ORSTOM, 1993.

[96] A. Seck, in Dakar, Métropole Ouest Africaine, p. 136, IFAN, Dakar, Senegal, 1970.

[97] ANS, “4P 133, Urbanisme à Dakar: aménagement de la Médina, plan d'extension," 1927.

[98] ANS, “4P 1514: mosquée de Dakar,” 1938.

[99] ANS, “4P 1537: construction d'un Marché couvert à Médina," 1940.

[100] ANS, “4P 512: residence de Médina,” 1941.

[101] ANS, 4P 141 and 144: Médina, secteur 2B, plans et devis, $1940-1955$.

[102] J. Bugnicourt, "Dakar without bounds," in Reading the Contemporary African City, the Aga Khan Award for Architecture, pp. 27-42, Concept Media, Singapore, 1982.

[103] ANS, H22, l'Hygiène à Dakar, 1919-1920 (Rapport sur l'hygiène à Dakar de 1899-1920).

[104] ANS, H22, l'Hygiène à Dakar, 1919-1920 (Rapport sur l'hygiène à Dakar de 1899-1920), p. 384.

[105] ANS, H22, l'Hygiène à Dakar, 1919-1920 (Rapport sur l'hygiène à Dakar de 1899-920), p. 384.

[106] W. Johnson, in The Emergence of Black Politics in Senegal: The Struggle for Power in the Four Communes, 1900-1920, pp. 3037, Stanford University Press, Stanford, Calif, USA, 1971.

[107] CAOM, "FM 1tp/95: création d'un village de segregation, expropriation des terrains du village indigène de Médina près Dakar," 1915.

[108] ANS, P190: Village de Médina, création de village, 19151919.

[109] C. Coquery-Vidrovitch, "Émeutes urbaines, grèves générales et décolonisation en Afrique française," in Les Chemins de la Décolonisation de l'Empire Français, 1936-1956, R. Ageron, Ed., pp. 493-504, CNRS, Paris, France, 1986.

[110] Démocratie du Sénégal, 1914.

[111] A. Conklin, A Mission to Civilize: The Republican Idea of Empire in France and West Africa, 1895-1930, Stanford University Press, Stanford, Calif, USA, 2000.

[112] ANS, “H55: peste à Dakar," 1914.

[113] Travaux Publics de l'AOF, "I'Urbanisme en Afrique occidentale Française," in l'Urbanisme aux Colonies et Dans les Pays Tropicaux, J. Royer, Ed., pp. 146-157, Delayance, La Charité Sur Loire, France, 1932.

[114] F. D. Lugard, The Dual Mandate in British Tropical Africa, William Blackwood \& Sons, London, UK, 1921.

[115] ANS, P190, Village de Médina, création de village, 1915-1919 (paragraph no. 5). 


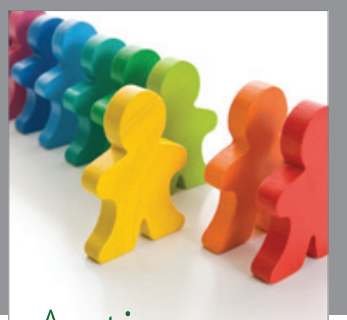

Autism

Research and Treatment
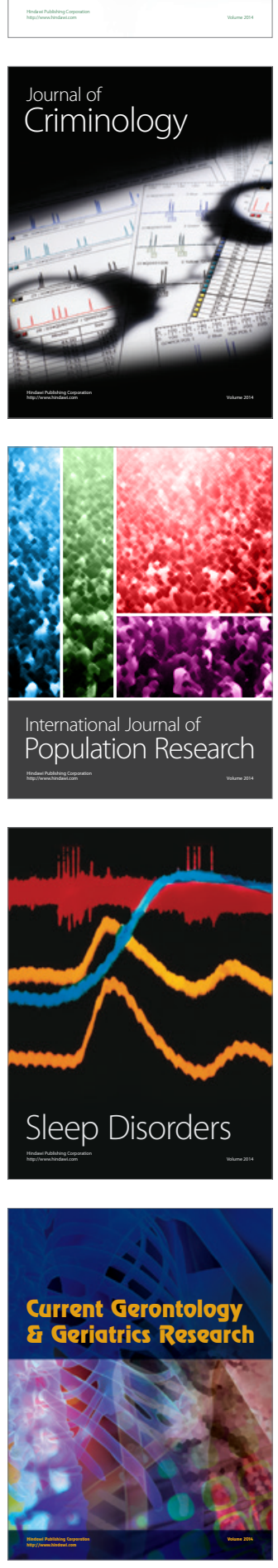
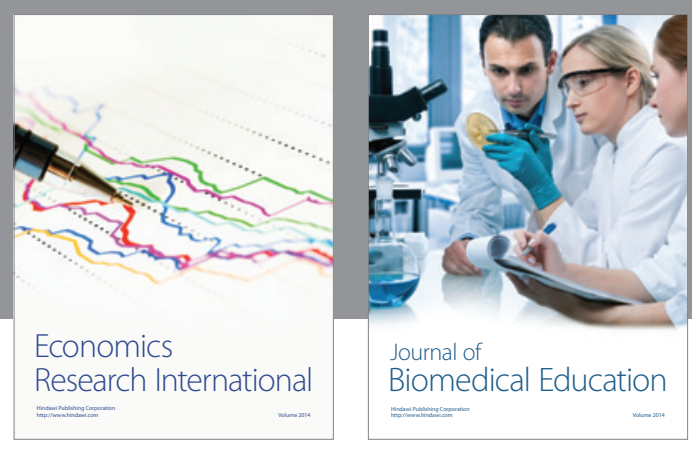

Journal of

Biomedical Education

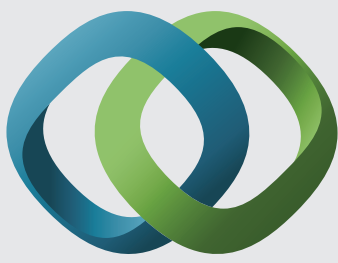

\section{Hindawi}

Submit your manuscripts at

http://www.hindawi.com
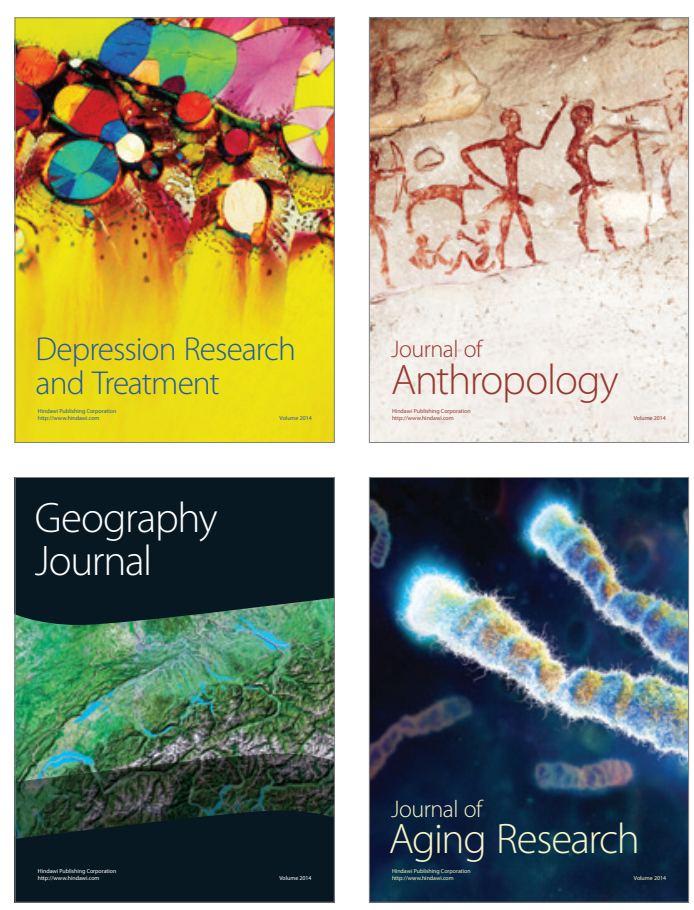

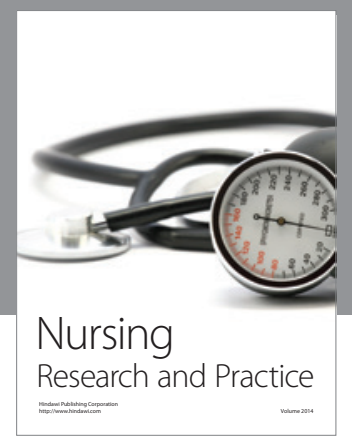

Nursing

Research and Practice

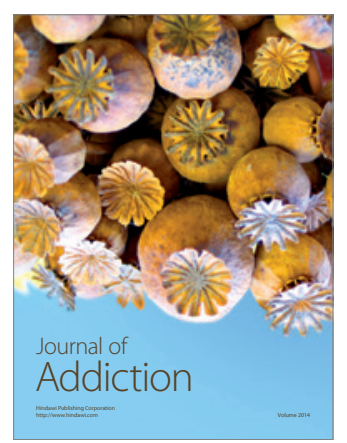

Child Development

Research

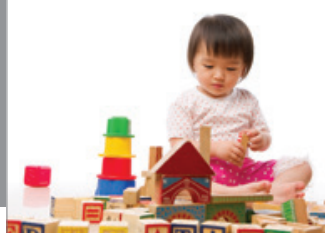

迥
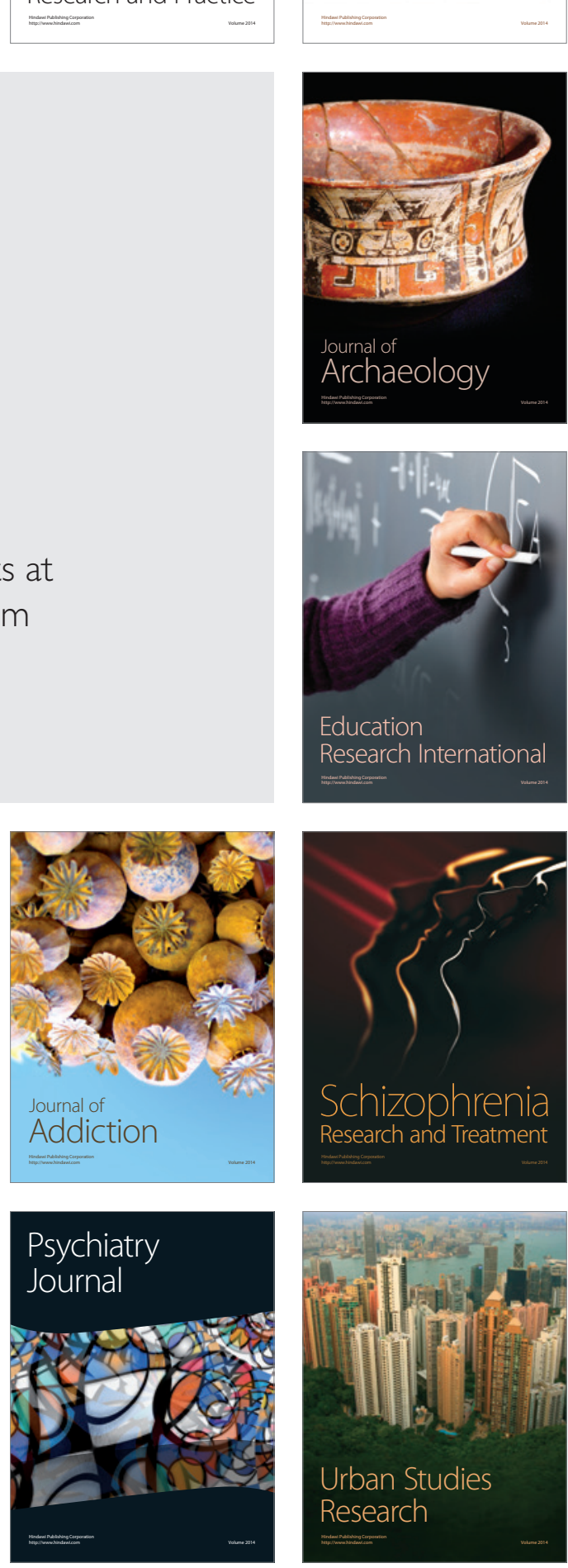